\title{
Effects of restrictions on maternal feed intake on the immune indexes of umbilical cord blood and liver Toll-like receptor signaling pathways in fetal goats during pregnancy
}

Wenxun Chen ${ }^{1,2}$, Qiongxian Yan ${ }^{1 *}$ (D) Hong Yang ${ }^{1,2}$, Xiaoling Zhou ${ }^{1,2,3}$ and Zhiliang Tan ${ }^{1,4,5}$

\begin{abstract}
Background: Liver has important immune function during fetal development and after birth. However, the effect of maternal malnutrition on immune function of the fetal liver is rarely reported. In this study, twelve pregnant goats (Xiangdong black goat, at d 45 of gestation) were assigned to the control group (fed 100\% of nutritional requirements) and the restriction group (fed $60 \%$ of the intake of the control group) during gestation from d 55 to 100. Fetal goats were harvested at $d 100$ of gestation and immune indexes and amino acid profiles of the umbilical cord blood and liver Toll-like receptors (TLRs) signaling pathways were measured.

Results: Maternal body weight in the restriction group was lower than the control group $(P<0.05)$. Maternal feed intake restriction decreased $(P<0.05)$ heart weight, heart index, alkaline phosphatase and serum amyloid protein $\mathrm{A}$ in the umbilical cord blood (UCB). Moreover, only histidine was decreased in the restricted group $(P=0.084)$, and there were no differences in other amino acids contents in the UCB between the two groups $(P>0.05)$. The TLR2 and TLR4 mRNA expression in the fetal liver in the restriction group was greater $(P<0.05)$ than that in the control group. Furthermore, the mRNA expression levels of myeloid differentiation primary response 88 (MyD88), TNF receptor associated factor 6 , nuclear factor kappa B subunit 1, NFKB inhibitor alpha, IFN- $\beta$, TGF- $\beta$, TNF- $\alpha$ and IL-1 $\beta$ in the restricted group were upregulated $(P<0.05)$, and the expression of TLR3 $(P=0.099)$ tended to be higher in the restricted group. However, protein levels of TLR2, TLR4, IKBa, phosphorylated IKBa, phosphorylated IKBa/total IkBa, TRIF and MyD88 were not affected $(P>0.05)$ by maternal intake restriction.

Conclusions: These results revealed that the restriction of maternal feed intake influenced the development of heart and hepatic protein synthesis at the acute phase of fetal goats and upregulated the mRNA expression of genes involved in MyD88-dependent signaling pathways and of target cytokines.
\end{abstract}

Keywords: Feed intake restriction, Fetal goats, Immune cell, Liver, TLRs signaling pathway

\footnotetext{
* Correspondence: yanqx14@isa.ac.cn

${ }^{1}$ CAS Key Laboratory for Agro-Ecological Processes in Subtropical Region,

National Engineering Laboratory for Pollution Control and Waste Utilization in Livestock and Poultry Production, Hunan Provincial Engineering Research Center for Healthy Livestock and Poultry Production, South-Central Experimental Station of Animal Nutrition and Feed Science in Ministry of Agriculture, Institute of Subtropical Agriculture, Chinese Academy of Sciences, Changsha, Hunan 410125, People's Republic of China

Full list of author information is available at the end of the article
} Commons Attribution 4.0 International License (http://creativecommons.org/licenses/by/4.0/), which permits unrestricted use, distribution, and reproduction in any medium, provided you give appropriate credit to the original author(s) and the source, provide a link to the Creative Commons license, and indicate if changes were made. The Creative Commons Public Domain Dedication waiver (http://creativecommons.org/publicdomain/zero/1.0/) applies to the data made available in this article, unless otherwise stated. 


\section{Background}

Maternal malnutrition during pregnancy often leads to intrauterine growth restriction (IUGR) where some visceral organs of IUGR fetuses experience structural changes and impaired function. Epidemiological studies have shown that adult diseases, such as abdominal adiposity, hypertension, dyslipidemia, glucose intolerance, type 2 diabetes and cardiovascular disease are associated with low-birth weight $[3,4]$. Fetal malnutrition usually induces permanent anatomical and functional changes in various tissues and organs $[18,20]$. These early insults at critical stages of development often lead to permanent changes in tissue structure and function for mammals; this process is known as intrauterine programming [14]. Meanwhile, it is also confirmed that organisms have the ability to change structure and function in response to environmental signals; this process is called developmental plasticity [16].

The liver has multiple important physiological functions during embryonic development and after birth including hematopoiesis, metabolism and immunity. The liver has a unique vascular system that receives blood from the digestive tract through the portal vein so that the liver is continuously exposed to the environment of pathogenic microorganisms [28]. Continuously stimulated by these gastrointestinal antigens, the liver forms a unique immune response through series of pattern recognition receptors, primarily Toll-like receptors (TLRs). Many kinds of cells in the liver express TLRs, including lymphocytes, Kupffer cells, dendritic cells, hepatocytes, hepatic stellate cells, and sinusoidal endothelial cells [10]. TLRs recognize numerous pathogen-associated molecular patterns (PAMPs) in vitro and in vivo and serve as an important part of the innate immune system. The TLRs recognize bacteria, DNA or RNA, viruses, fungi and protozoa and then activate the immune system to promote the production of inflammatory cytokines and bacitracin that help the body to clear the pathogen and maintain homeostasis [30].

It is well-known that maternal nutrition is critical to the development of human immune system [8]. Animal data suggest that nutritional restriction during gestation shows persistent immunological impairment for several months [9]. He et al. [19] reported that a $40 \%$ maternal protein or energy restriction during late gestation decreases the baseline immune status in neonatal goats and alters immune responses to challenges later in life. Equils et al. [13] found that maternal starvation downregulates hepatic TLR4 expression and function during intrauterine growth in the offspring of prenatal calorie-restricted rats. Therefore, we wondered whether maternal malnutrition affects immune system development especially regarding TLR expression in the innate immune system. The liver is an important site of immune precursor cell development and differentiation during early pregnancy [21]. However, the immune status of the fetal liver responding to maternal malnutrition is still unclear. Furthermore, the mother's system may respond to malnutrition by programming nutrient partitioning to change growth rate and function of the major fetal organs [11]. Hence, how to allocate the limited nutrient partitioning to improve innate immune system function in response to pathogen invasion after birth needs to be investigated.

Therefore, the objective of this study was to assess the immune status of fetal goats in response to maternal feed intake restriction in the middle of the gestation period. Understanding the effects of maternal nutrition on the innate immune system and TLR pathway may potentially help to develop novel strategies to improve the body weight of newborn goats to ensure a higher survival rate.

\section{Material and methods}

The experiments were conducted according to the Animal Care and the Use Guidelines of the Animal Care Committee, Institute of Subtropical Agriculture, Chinese Academy of Sciences, Changsha, China.

\section{Animal management and dietary treatments}

Twelve goats $(33.4 \pm 7.9 \mathrm{~kg}$ at $45 \pm 3 \mathrm{~d}$ of pregnancy, Xiangdong black goat, local meat breed) were selected and randomly assigned into two groups: the control group [fed $100 \%$ of maintenance requirements as reference to Chinese meat goat requirement (2004), $n=6$ ] and the restriction group (fed $60 \%$ of the control group during d 55 to 100 of gestation, $n=6$ ). All animals were penned individually, fed with a 50:50 ratio of concentrate to roughage twice per day (at 08:00 and 16:00), and this protocol lasted from d 45 to 55 of gestation. The feed intake of each experimental goat was recorded during the adaptation period. During the complete restriction period from d 55 to 100 of gestation, feed allowance of the control group was adjusted by $10 \%$ upwardly or downwardly per week in order to maintain leftover feed was not higher than $10 \%$ and corresponding intake adjustment was performed in the restriction group to maintain $60 \%$ intake of the control group. Ingredients and composition of the experimental diet for the pregnant goats are listed in Table 1.

\section{Tissue sample collection}

All the pregnant goats were anesthetized with an intravenous injection of sodium pentobarbital $(50 \mathrm{mg} / \mathrm{kg} \mathrm{BW})$ and slaughtered at d 100 of gestation before feeding in the morning. Twelve fetuses ( 5 males and 7 females) from the control group and twelve fetuses ( 6 males and 6 females) from the restriction group were collected. At slaughter, the fetal body weight, sex and multiple births were recorded. The heart, liver, spleen, kidney and lung were then weighed immediately. Liver tissues were washed with iced PBS to remove the bloody dirt and then cut into small pieces. Liver samples were immediately frozen in liquid nitrogen and stored at $-80^{\circ} \mathrm{C}$ before analysis. 
Table 1 Ingredients and composition of experimental diets for pregnant Xiangdong black goats, DM basis

\begin{tabular}{ll}
\hline Item & Content \\
\hline Ingredients, \% & \\
Miscanthus & 54.41 \\
Maize & 30.55 \\
Soybean meal & 9.41 \\
Fat power & 3.65 \\
Calcium carbonate & 0.44 \\
Calcium bicarbonate & 0.42 \\
Sodium chloride & 0.21 \\
Premix & \\
Composition & b \\
Metabolic energy, MJ/kg & 0.91 \\
Crude protein, \% & \\
Ether extract, \% & 9.11 \\
Neutral detergent fiber, \% & 7.19 \\
Acid detergent fiber, \% & 8.97 \\
Ash, \% & 64.44 \\
Calcium, \% & 28.32 \\
Phosphorus, \% & 5.89 \\
\hline
\end{tabular}

${ }^{\mathrm{a}}$ Contained per kg: $119 \mathrm{~g} \mathrm{MgSO}_{4} \cdot \mathrm{H}_{2} \mathrm{O}, 2.5 \mathrm{~g} \mathrm{FeSO}_{4} \cdot 7 \mathrm{H}_{2} \mathrm{O}, 0.8 \mathrm{~g} \mathrm{CuSO}_{4} \cdot 5 \mathrm{H}_{2} \mathrm{O}, 3 \mathrm{~g}$ $\mathrm{MnSO}_{4} \cdot \mathrm{H}_{2} \mathrm{O}, 5 \mathrm{~g} \mathrm{ZnSO}_{4} \cdot \mathrm{H}_{2} \mathrm{O}, 10 \mathrm{mg} \mathrm{Na}{ }_{2} \mathrm{SeO}_{3}, 40 \mathrm{mg} \mathrm{KI}, 30 \mathrm{mg} \mathrm{CoCl} \cdot 6 \mathrm{H}_{2} \mathrm{O}$, 95,000 IU vitamin A, 17,500 IU vitamin D, 18,000 IU vitamin $\mathrm{E}$

${ }^{\mathrm{b}}$ Crude protein, ether extract, neutral detergent fiber, acid detergent fiber, ash, calcium and phosphorus were determined values, and metabolic energy was calculated according to the data of Zhang [33]

\section{Blood sampling and analysis}

Blood samples were collected by venipuncture from umbilical cord after ligation. A portion of the sample was injected into tubes containing sodium heparin while the remainder of the sample was allowed to coagulate for $40 \mathrm{~min}$ before centrifugation $(3500 \times g, 10 \mathrm{~min})$. The isolated serum and plasma samples were then stored at $80^{\circ} \mathrm{C}$ until analysis. The examination of plasma albumin (ALB), alkaline phosphatase (ALP) and haptoglobin were performed by automatic biochemistry analyzer (cobas $\mathrm{C}$ 311 , Roche). Serum amyloid protein A (SAA), paraoxonase (PON) and IL-6 were assayed using corresponding commercially available ELISA kits (CUSABIO; MEIMIAN). An analysis of amino acid content in blood was performed using an amino acid analyzer (L8800, Hitachi Ltd., Tokyo, Japan). Seventeen individual amino acids were measured. Measured amino acids were divided into essential amino acids and nonessential amino acids.

\section{Total RNA extraction and qPCR}

Total RNA was isolated from liver samples using Trizol (R1100; Solarbio) according to the manufacturer's protocol. RNA quality was verified by both agarose gel (1\%) electrophoresis and spectrometry (A260/A280, NanoDrop
2000; Thermo Scientific.). First-strand cDNA was generated in duplicate using the PrimeScript ${ }^{\mathrm{Tm}} \mathrm{RT}$ reagent Kit with gDNA Eraser (RR047A; Takara). Primers (Table 2) for the target genes and the reference gene were designed and synthesized by Sangon Biotech (Shanghai; China). In the current study, the $\beta$-actin gene was chosen as the reference gene. Real-time qPCR was performed in triplicate

Table 2 Primer sequences for the mRNA expression analysis of genes

\begin{tabular}{|c|c|c|}
\hline Gene name & Primers (5' to $3^{\prime}$ ) & Length, bp \\
\hline ActinB ( $\beta$-actin) & $\begin{array}{l}\text { F: ATGGCTACTGCTGCGTCGT } \\
\text { R: TTGAAGGTGGTCTCGTGGAT }\end{array}$ & 161 \\
\hline Toll-like receptor 2 (TLR2) & $\begin{array}{l}\text { F: ACGACGCCTTTGTGTCCTAC } \\
\text { R: GGGACGAAGTCTCGCTTATG }\end{array}$ & 121 \\
\hline Toll-like receptor 3 (TLR3) & $\begin{array}{l}\text { F: ATTGGGCAAGAACTCACAGG } \\
\text { R: AGGCTTGGAACTGAGGTGAA }\end{array}$ & 119 \\
\hline Toll-like receptor 4 (TLR4) & $\begin{array}{l}\text { F: ACTCCCTCCCTAGCCTTCAG } \\
\text { R: GCCGTGATACGGTTGAAACT }\end{array}$ & 124 \\
\hline Toll-like receptor 7 (TLR7) & $\begin{array}{l}\text { F: GTTCCATTTCCTTGCACACC } \\
\text { R: GGGCACATGCTGAAGAGAGT }\end{array}$ & 123 \\
\hline $\begin{array}{l}\text { Myeloid differentiation } \\
\text { primary response } 88 \text { (MyD88) }\end{array}$ & $\begin{array}{l}\text { F: GAGGACGTGCTGATGGAACT } \\
\text { R: CGAGGGATGCTGCTGTCTAT }\end{array}$ & 125 \\
\hline $\begin{array}{l}\text { Interleukin-1 receptor- } \\
\text { associated kinase } 1 \text { (IRAK1) }\end{array}$ & $\begin{array}{l}\text { F: GACACCGACACCTTCAGCTT } \\
\text { R: TGCCTCCTCTTCAACCAAGT }\end{array}$ & 117 \\
\hline $\begin{array}{l}\text { TNF receptor associated } \\
\text { factor } 6 \text { (TRAF6) }\end{array}$ & $\begin{array}{l}\text { F: CAGCAGTGCAATGGGATTA } \\
\text { R: CCGGGTTTGCAGTATAGAA }\end{array}$ & 119 \\
\hline $\begin{array}{l}\text { Toll like receptor adaptor } \\
\text { molecule } 1 \text { (TRIF) }\end{array}$ & $\begin{array}{l}\text { F: ACTTCTCACAGGCACCACCT } \\
\text { R: GGTCCCTCTCTGATTCCACA }\end{array}$ & 119 \\
\hline TANK-binding kinase 1 (TBK1) & $\begin{array}{l}\text { F: TGATCACGTTGGATTTCTGC } \\
\text { R: GCTTGGTGCGTATGTCTGAA }\end{array}$ & 120 \\
\hline $\begin{array}{l}\text { Nuclear factor kappa B } \\
\text { subunit } 1 \text { (NFKB1) }\end{array}$ & $\begin{array}{l}\text { F: GTGCTCGGTGGGAGTAAGAG } \\
\text { R: CTCCCGTCACTGCATAGTCA }\end{array}$ & 119 \\
\hline $\begin{array}{l}\text { NFKB inhibitor } \\
\text { alpha (NFKB1A) }\end{array}$ & $\begin{array}{l}\text { F: CTACACCTTGCCTGTGAGCA } \\
\text { R: CACGTGTGGCCATTGTAGTT }\end{array}$ & 116 \\
\hline $\begin{array}{l}\text { Interferon regulatory } \\
\text { factor } 3 \text { (IRF3) }\end{array}$ & $\begin{array}{l}\text { F: GACCAGCCATGGATCAAGAG } \\
\text { R: CAGGTCGACAGTGTTCTCCA }\end{array}$ & 117 \\
\hline $\begin{array}{l}\text { Interferon regulatory } \\
\text { factor } 7 \text { (IRFT) }\end{array}$ & $\begin{array}{l}\text { F: TGGCAGCAGATACTGGTGAG } \\
\text { R: GAAGATGGTCCTCCAAGCAG }\end{array}$ & 129 \\
\hline Interferon beta (IFN- $\beta$ ) & $\begin{array}{l}\text { F: CCATCATTGAGCACCTCCTT } \\
\text { R: AGGTGAAGATCGGTCGTGTC }\end{array}$ & 118 \\
\hline Interferon gamma (IFN- $\gamma)$ & $\begin{array}{l}\text { F: GAACGGCAGCTCTGAGAAAC } \\
\text { R: ATITTGGCGACAGGTCATTC }\end{array}$ & 125 \\
\hline $\begin{array}{l}\text { Transforming Growth } \\
\text { factor beta } 1 \text { (TGF- } \beta \text { ) }\end{array}$ & $\begin{array}{l}\text { F: GAACTGCTGTGTTCGTCAGC } \\
\text { R: TCCAGGCTCCAGATGTAAGG }\end{array}$ & 126 \\
\hline $\begin{array}{l}\text { Tumor necrosis } \\
\text { factor (TNF-a) }\end{array}$ & $\begin{array}{l}\text { F: CCACTGACGGGCTITACCT } \\
\text { R: TGATGGCAGAGAGGATGTTG }\end{array}$ & 141 \\
\hline Interleukin 1 beta (IL-1 $\beta)$ & $\begin{array}{l}\text { F: AAGCCTCTCCACCTCCTCTC } \\
\text { R: TTGTCCCTGATACCCAAGG }\end{array}$ & 114 \\
\hline Interleukin 2 (IL-2) & $\begin{array}{l}\text { F: GTGAAGTCATTGCTGCTGGA } \\
\text { R: GCGTTAACCTTGGGCATGTA }\end{array}$ & 113 \\
\hline Interleukin 4 (IL-4) & $\begin{array}{l}\text { F: CATCCTCACATCGCAGAAGA } \\
\text { R: ACGCCTAAGCTCAATTCCAG }\end{array}$ & 118 \\
\hline Interleukin 6 (IL-6) & $\begin{array}{l}\text { F: TGACTTCTGCTTTCCCTACCC } \\
\text { R: GCCAGTGTCTCCTTGCTGTT }\end{array}$ & 193 \\
\hline Interleukin 10 (IL-10) & $\begin{array}{l}\text { F: GCTGTTGCCTGGTCTTCCT } \\
\text { R: TGTTCAGTTGGTCCTTCATTTG }\end{array}$ & 178 \\
\hline
\end{tabular}


to amplify the target genes and $\beta$-actin using the $2 \times$ SYBR Green I PCR mix (Solarbio, SR1110). Reactions were performed in the Roche LightCycler 480II Sequence Detection System. The thermal cycling parameters were as follows: $95^{\circ} \mathrm{C}$ for $10 \mathrm{~min}$ for activating the hotstart DNA polymerase, and then cycled at $95^{\circ} \mathrm{C}$ for $20 \mathrm{~s}$ and $60^{\circ} \mathrm{C}$ for 1 min for 40 cycles of amplification.

Relative mRNA abundance was determined using the $\triangle$ cycle threshold $(\triangle \mathrm{Ct}$ ) method [25]. In brief, a $\triangle \mathrm{Ct}$ value is the $\mathrm{Ct}$ difference between the target gene and the reference gene $\left(\triangle \mathrm{Ct}=\mathrm{Ct}_{\text {target }}-\mathrm{Ct}_{\text {reference }}\right)$. For each of the target genes, the $\triangle \triangle \mathrm{Ct}$ values of all the samples were calculated by subtracting the average $\triangle \mathrm{Ct}$ of the corresponding Control/Restriction group. The relative expression ratio of mRNA was calculated by $\mathrm{R}=2^{-\Delta \Delta \mathrm{Ct}}$.

\section{Western blot analysis}

Immunoblotting for TLR2, TLR4, MyD88, TRIF, IкB $\alpha$, and phosphorylated IкB $\alpha$ in the liver samples were performed. Briefly, equal amounts of protein $(75-130 \mu \mathrm{g})$ were subjected to $10 \%$ SDS-polyacrylamide gel electrophoresis, and separated proteins were transferred to a polyvinylidene fluoride membrane. The membranes were blocked with $5 \%$ nonfat dry milk in tris-buffered saline (TBST) buffer at room temperature for $1 \mathrm{~h}$. Then, the membranes were incubated with Anti-TLR2 antibody (Abcam, ab191458; 1:20,000 dilution), Anti-TLR4 antibody (Abcam, ab13556; 1:1,000 dilution), Anti-MyD88 antibody (SIGMA, SAB2104398-50UG; 1:2,000 dilution), Anti-TRIF antibody (Abcam, ab205363; 1:500 dilution), Anti-IкB $\alpha$ antibody (CST, 9242S; 1:1,000 dilution) and Anti-phosphorylated IкB $\alpha$ antibody (CST, 9246S; 1:1,000 dilution) in TBST including 5\% BSA overnight at $4{ }^{\circ} \mathrm{C}$. This was followed by an incubation with horseradish peroxidase-conjugated secondary antibodies (Beyotime, $\mathrm{CN}$ ) in TBST including $0.1 \%$ BSA at $1: 1,000$ for $1 \mathrm{~h}$ at room temperature. The immunoreactive proteins were detected using ECL Prime Western blotting detection reagent by enhanced chemiluminescence. Densitometric analysis was performed with Image 1.42 r (National Institutes of Health, USA) software. $\beta$-actin was used to normalize the expression of proteins in each sample.

\section{Statistical analyses}

Data were analyzed using the MIXED procedure of IBM SPSS Statistics Version 22. Maternal feed intake restriction and fetal sex were considered fixed effects and the interaction of feed intake restriction $\times$ fetal sex was considered in the model. Differences were considered significant at $P<0.05$, and $P$-values between 0.05 and 0.10 were considered trending towards significance.

\section{Results}

Dry matter intake and body weight of maternal goats As shown in Table 3, the actual dry matter intake of pregnant goats in the restriction group was $52.63 \%$ of that in the control group $(P<0.001)$. Meanwhile, maternal body weight of the restriction group was lower than that of the control group $(P<0.05)$.

\section{Fetal body weight, visceral organs development and umbilical cord blood analysis}

At d 100 of gestation, fetal body weight showed no difference between the two groups $(P>0.05)$ but the heart weight and index of fetal goats from the restriction group was lower $(P<0.05)$ than that of the control group. However, the weights and organ indices of the liver, spleen, kidney and lung were unaffected $(P>0.05)$ by maternal intake restriction (Table 4 ). All these parameters were not affected by fetal sex $(P>0.05)$. The interaction between maternal feed intake restriction and fetal sex affected fetal body weight, spleen weight, heart index and spleen index $(P<0.05)$.

As illustrated in Table 5, the concentrations of ALB and PON of umbilical cord blood albumin were not affected $(P>0.05)$ by maternal intake restriction, but the concentrations of ALP and SAA in the restriction group were lower $(P<0.05)$ than those of the control group. In addition, fetal sex affected the ALP concentration (109.43 $\mathrm{U} / \mathrm{L}$ in females vs $92.50 \mathrm{U} / \mathrm{L}$ in males). There was no interaction between maternal feed intake restriction and fetal sex on all these indexes.

When the amino acids of the umbilical cord blood were examined (Table 6$)$, only histidine $(P=0.084)$ had a decreasing tendency, and there were no differences for other individual amino acids, total essential amino acids, total nonessential amino acids, and total amino acids between the control and restriction groups $(P>0.05)$. Additionally, amino acid concentrations were not influenced by fetal sex $(P>0.05)$.

\section{Expression of TLRs signaling pathway-associated genes in the liver of fetal goats}

The mRNA abundance of TLR2, TLR4, myeloid differentiation primary response $88(M y D 88), T N F$ receptor-associated factor 6 (TRAF6), nuclear factor kappa B subunit 1 (NFKB1), NF-kappa-B inhibitor alpha (NFKBIA), IFN- $\beta, T G F-\beta$, tumor

Table 3 Dry matter intake and maternal body weight of the Xiangdong black goats during the pregnancy

\begin{tabular}{lllll}
\hline Item & $\begin{array}{l}\text { Control } \\
\text { group }\end{array}$ & $\begin{array}{l}\text { Restriction } \\
\text { group }\end{array}$ & SEM & P-value \\
\hline DMl, kg/d & 1.14 & 0.60 & 0.04 & $<0.001$ \\
$\begin{array}{l}\text { Maternal body weight } \\
\text { at d100, kg }\end{array}$ & 39.85 & 32.14 & 1.17 & 0.008 \\
\hline
\end{tabular}

DMI dry matter intake 
Table 4 Body weight, organ weights and indices of the fetal Xiangdong black goats during the pregnancy

\begin{tabular}{lllllll}
\hline Item & Control group & Restriction group & SEM & $P_{\text {treatment }}$ & $P_{\text {sex }}$ & $P_{\text {treatment } \times \text { sex }}$ \\
\hline Body weight at d 100, g & 638.97 & 564.58 & 36.04 & 0.344 & 0.996 & 0.041 \\
Heart, g & 5.64 & 4.38 & 0.24 & 0.006 & 0.840 & 0.246 \\
Liver, g & 39.86 & 34.41 & 2.74 & 0.249 & 0.799 & 0.188 \\
Spleen, g & 0.72 & 0.66 & 0.11 & 0.757 & 0.950 & 0.018 \\
Kidney, g & 7.25 & 6.79 & 0.53 & 0.978 & 0.663 & 0.087 \\
Lung, g & 18.37 & 16.38 & 1.43 & 0.501 & 0.473 & 0.055 \\
Heart weight: BW, \%o & 8.92 & 7.77 & 0.23 & $<0.001$ & 0.844 & 0.028 \\
Liver weight: BW, \%o & 62.28 & 61.03 & 1.67 & 0.350 & 0.439 & 0.296 \\
Spleen weight: BW, \%o & 1.09 & 1.15 & 0.10 & 0.217 & 0.828 & 0.020 \\
Kidney weight: BW, \%o & 11.35 & 11.95 & 0.55 & 0.316 & 0.454 & 0.521 \\
Lung weight: BW, \%o & 29.08 & 28.69 & 1.44 & 0.906 & 0.454 & 0.622 \\
\hline
\end{tabular}

BW body weight

necrosis factor $(T N F-\alpha)$ and $I L-1 \beta(P<0.05)$ were increased in the fetal liver of the restriction group (Table 7). The expression of TLR3 $(P=0.099)$ tended to be higher in the restriction group. In addition, the expression of TNF- $\alpha$ (1.91 in females vs 1.10 in males) was affected by fetal sex, and MyD88 (1.55 in females vs 1.19 in males) and TRIF (1.29 in females vs 1.06 in males) transcripts in female fetal goats tended to be greater than that of males. The mRNA expression of TLR7, IRAK1, $N F K B 1, T N F-\alpha$ and $I L-1 \beta$ was also affected by the interaction between maternal feed intake restriction and fetal sex $(P<0.05)$.

To investigate the effects of intake restriction on NF-kappa-B inhibitor alpha ( $\mathrm{I} B \mathrm{~B} \alpha)$ expression and activation, the protein expression of IKB $\alpha$ and its phosphorylation at $\mathrm{Ser}^{32 / 36}$ were measured in the liver of fetal goats. As shown in Fig. 1, maternal intake restriction had no effect $(P>0.05)$ on the expression of TLR2, TLR4, TRIF, MyD88, IкB $\alpha$, and phosphorylated IкB $\alpha$ or on the ratio of phosphorylated ІкB $\alpha$ to total ІкB $\alpha$. All of these protein abundances were not affected by fetal sex $(P>0.05)$. There was an interaction between maternal feed intake restriction and fetal sex on MyD88 and phosphorylated IкB $\alpha(P<0.05)$.

Table 5 Indexes of the umbilical cord blood in fetal Xiangdong black goats during the pregnancy

\begin{tabular}{lllllll}
\hline Item & $\begin{array}{l}\text { Control } \\
\text { group }\end{array}$ & $\begin{array}{l}\text { Restriction } \\
\text { group }\end{array}$ & SEM & $P_{\text {treatment }}$ & $P_{\text {sex }}$ & $P_{\text {treatment } \times \text { sex }}$ \\
\hline ALB, g/L & 20.23 & 20.80 & 0.53 & 0.794 & 0.142 & 0.268 \\
ALP, U/L & 112.22 & 84.78 & 8.75 & $<0.001$ & 0.003 & 0.203 \\
PON, U/L & 175.61 & 178.30 & 8.83 & 0.647 & 0.687 & 0.532 \\
SAA, g/mL & 2189.41 & 1493.30 & 144.33 & 0.037 & 0.342 & 0.360 \\
\hline
\end{tabular}

$A L B$ albumin, $A L P$ alkaline phosphatase, $P O N$ paraoxonase, $S A A$ serum amyloid protein A

\section{Discussion}

The aim of this experiment was to characterize the immune status of fetal livers in response to maternal feed intake restriction during the middle period of gestation. Currently, a $40 \%$ intake restriction during the middle period of gestation ( $\mathrm{d} 55-100)$ in goats was

Table 6 Amino acids concentration in the umbilical cord blood of fetal Xiangdong black goats

\begin{tabular}{|c|c|c|c|c|c|c|}
\hline Item & $\begin{array}{l}\text { Control } \\
\text { group }\end{array}$ & $\begin{array}{l}\text { Restriction } \\
\text { group }\end{array}$ & SEM & $P_{\text {treatment }}$ & $P_{\text {sex }}$ & $P_{\text {treatment } \times \text { sex }}$ \\
\hline \multicolumn{7}{|l|}{ EAA } \\
\hline Thr & 164.27 & 166.76 & 23.98 & 0.884 & 0.635 & 0.178 \\
\hline Val & 404.41 & 374.95 & 49.88 & 0.524 & 0.530 & 0.178 \\
\hline Met & 387.77 & 299.21 & 60.21 & 0.233 & 0.891 & 0.268 \\
\hline \|le & 163.31 & 175.79 & 19.01 & 0.785 & 0.760 & 0.177 \\
\hline Leu & 302.67 & 313.81 & 44.34 & 0.989 & 0.765 & 0.225 \\
\hline Phe & 190.08 & 211.64 & 31.85 & 0.776 & 0.850 & 0.184 \\
\hline His & 118.76 & 90.70 & 16.41 & 0.084 & 0.229 & 0.130 \\
\hline Lys & 442.71 & 475.14 & 69.14 & 0.874 & 0.874 & 0.320 \\
\hline \multicolumn{7}{|l|}{ NEAA } \\
\hline Asp & 110.97 & 84.64 & 26.94 & 0.330 & 0.711 & 0.325 \\
\hline Ser & 1047.16 & 1151.63 & 76.93 & 0.907 & 0.543 & 0.140 \\
\hline Glu & 634.23 & 696.91 & 117.79 & 0.808 & 0.869 & 0.843 \\
\hline Gly & 607.13 & 719.13 & 68.78 & 0.324 & 0.195 & 0.074 \\
\hline Ala & 663.13 & 491.30 & 56.65 & 0.137 & 0.864 & 0.346 \\
\hline Cys & 77.70 & 72.85 & 11.32 & 0.571 & 0.668 & 0.164 \\
\hline Tyr & 242.86 & 265.14 & 36.27 & 0.846 & 0.834 & 0.149 \\
\hline Arg & 188.46 & 240.39 & 35.28 & 0.808 & 0.911 & 0.718 \\
\hline Pro & 305.33 & 309.24 & 37.59 & 0.434 & 0.169 & 0.964 \\
\hline Total EAA & 2173.97 & 2108.00 & 243.12 & 0.695 & 0.858 & 0.196 \\
\hline Total NEAA & 4051.84 & 3953.70 & 487.11 & 0.745 & 0.572 & 0.212 \\
\hline $\begin{array}{l}\text { Total amino } \\
\text { acid }\end{array}$ & 6225.82 & 6061.71 & 721.15 & 0.717 & 0.655 & 0.190 \\
\hline
\end{tabular}


Table 7 Expression of toll-like receptor signaling pathway genes in fetal Xiangdong black goats liver during the pregnancy

\begin{tabular}{lllllll}
\hline Item & $\begin{array}{c}\text { Control } \\
\text { group }\end{array}$ & $\begin{array}{l}\text { Restriction } \\
\text { group }\end{array}$ & SEM & $P_{\text {treatment }}$ & $P_{\text {sex }}$ & $P_{\text {treatment } \times \text { sex }}$ \\
\hline MyD88-dependent & & & & & \\
TLR2 & 1.11 & 1.74 & 0.161 & 0.001 & 0.104 & 0.160 \\
TLR4 & 1.06 & 1.34 & 0.094 & 0.003 & 0.128 & 0.025 \\
TLR7 & 1.12 & 1.06 & 0.090 & 0.410 & 0.510 & 0.006 \\
MyD88 & 1.06 & 1.61 & 0.099 & $<0.001$ & 0.053 & 0.642 \\
IRAK1 & 1.05 & 1.28 & 0.096 & 0.356 & 0.273 & 0.029 \\
TRAF6 & 1.06 & 1.32 & 0.093 & 0.005 & 0.274 & 0.282 \\
IRF7 & 1.14 & 1.18 & 0.117 & 0.697 & 0.645 & 0.161 \\
NFKB1 & 1.08 & 1.33 & 0.094 & 0.008 & 0.636 & 0.027 \\
NFKBIA & 1.03 & 1.25 & 0.045 & $<0.001$ & 0.797 & 0.148 \\
MyD88-independent & & & & & \\
TLR3 & 1.06 & 1.15 & 0.070 & 0.099 & 0.671 & 0.071 \\
TRIF & 1.04 & 1.24 & 0.079 & 0.101 & 0.082 & 0.451 \\
TBK1 & 1.05 & 1.22 & 0.096 & 0.106 & 0.396 & 0.789 \\
IRF3 & 1.10 & 1.36 & 0.085 & 0.111 & 0.402 & 0.543 \\
Cytokine & & & & & & \\
IFN- $\beta$ & 1.08 & 1.32 & 0.088 & 0.034 & 0.207 & 0.689 \\
TGF- $\beta$ & 1.04 & 1.26 & 0.106 & 0.019 & 0.469 & 0.093 \\
TNF- $\alpha$ & 1.00 & 1.95 & 0.361 & $<0.001$ & 0.004 & 0.001 \\
IL-1 $\beta$ & 1.05 & 1.36 & 0.086 & $<0.001$ & 0.133 & $<0.001$ \\
\hline & & & & & & \\
\hline
\end{tabular}

chosen to explore the effects of maternal malnutrition on fetal growth and liver immunity. As a consequence, insufficient nutrient supply inhibited fetal cardiac development during pregnancy and decreased the concentrations of ALP and acute phase protein SAA in the umbilical cord blood. Our results are consistent with previous reports that protein or energy restriction during late gestation altered visceral organ mass [20]. Furthermore, no changes in fetal liver weight between the two groups were observed. It is reported that nutrient restriction during early gestation (from $\mathrm{d}$ 30 to $\mathrm{d} 85$ ) did not influence fetal liver mass in beef cows [11], but maternal undernutrition during late pregnancy (from d 90 to d 140) resulted in inhibited fetal hepatic growth and fibrosis, antioxidant imbalance, and dysfunction in sheep [15]. Generally, ALP plays an integral role in liver metabolism and skeleton development. The ALP activity in female fetuses was greater than that in males in our study. The positive acute phase proteins are regarded as having general functions in opsonization and trapping of microorganisms and their products in modulating the host's immune response [17]. However, other acute phase proteins (C-reaction protein, haptoglobin and ceruloplasmin) were not detected in the umbilical cord blood of the two groups, we speculate that these acute phase proteins were probably synthesized at a later stage of pregnancy.

Amino acids play critical roles in metabolism, body composition and immunity. Amino acids are required for the synthesis of a variety of specific proteins (cytokines and antibodies) and regulate key metabolic pathways of the immune response to infectious pathogens. In pigs, dietary protein deficiency decreased the umbilical venous plasma concentrations of alanine, arginine, branched-chain amino acids (BCAA; isoleucine, leucine and valine), cystine, glutamine, glycine, lysine, ornithine, proline, taurine and threonine at $\mathrm{d} 60$ of gestation [32]. In ovine, a 50\% nutritional restriction between $\mathrm{d} 28$ and $\mathrm{d} 78$ of gestation reduced concentrations of total $\alpha$-amino acids (particularly serine, arginine-family amino acids, and BCAA) in the fetal plasma [23]. However, in this study, there were no differences in any amino acids between the control and restriction groups. Our results indicate that the mobilization of the protein reserve in pregnant goats fed $60 \%$ of maintenance requirements during the middle gestation period appear to sufficiently compensate for the supply of amino acids for the fetuses.

Moderate dietary protein restriction during gestation impairs offspring thymocyte proliferation at birth and thymic and splenic lymphocyte proliferation at weaning in rats [7]. In addition, $\mathrm{T}$ lymphocytes from malnourished infants are dysfunctional and have a shorter life [2]. The liver usually contains many immune cells that are responsible for the clearance of foreign antigens, but whether these cells are functionally involved in triggering innate immunity is unclear. Equils et al. [13] have found that a 50\% daily food intake restriction from d 11 to 21 of gestation downregulated the hepatic TLR4 mRNA and protein expression in rats offspring but upregulated hepatic $I L-1 \beta$ and $T N F-\alpha$ mRNA expression, which have previously been shown to modulate TLR gene expression [1]. It was suggested that the effect of intrauterine growth restriction on hepatic TLR4 expression may be due to the dysregulation of baseline cytokine expression in the liver. In this experiment, we observed the mRNA levels of TLR signaling pathway genes, including $I L-1 \beta$ and TNF- $\alpha$, were upregulated in the restriction group. The increase in TNF- $\alpha$ mRNA expression in female versus male fetuses needs to be investigated in the future. We further noted the transcripts of TLR2, TLR4, MyD88 and NFKBIA were upregulated, but protein expression of TLR2, TLR4, MyD88 and total IкB $\alpha$ showed no difference between the two groups. The global reduction in protein translation and subtle changes of transcriptome in the fetal liver of nutrient restricted rats [6] may be ascribed to the differential expression at mRNA and protein levels. Additionally, mature miRNA generally can repress the protein translation process and regulate the abundance of mRNA target genes associated with the innate immune response [22, 31]. Several 


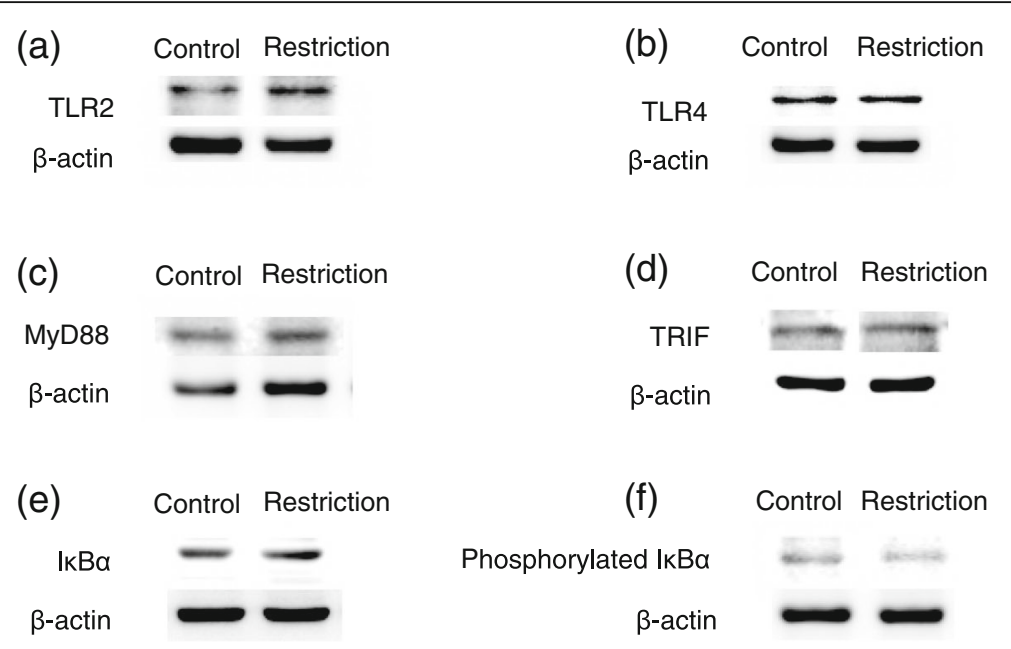

(g)

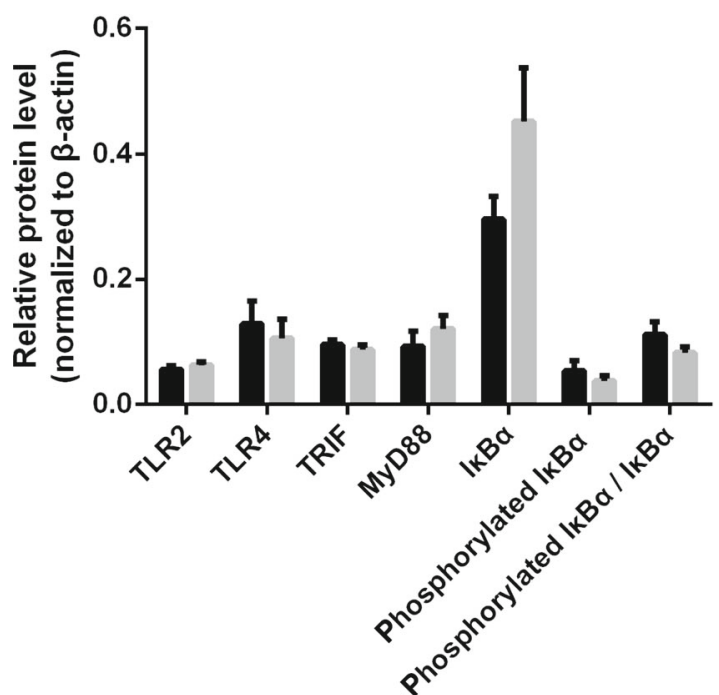

Control

Restriction

Fig. 1 Effects of maternal feed intake restriction on toll-like receptor signaling pathway protein expression of the fetal Xiangdong black goats liver. a-g TLR2, TLR4, MyD88, TRIF, IKBa and phosphorylated IKBa protein expression in fetal liver analyzed using Western blot. Maternal feed intake restriction and fetal sex did not affect the expression of TLR2, TLR4, MyD88, TRIF, IKBa, phosphorylated IkBa and ratio of phosphorylated $\mathrm{I} \mathrm{kBa}$ to total $\mathrm{I} \mathrm{KBa}$ in fetal liver $(P>0.05)$. There was an interaction between maternal feed intake restriction and fetal sex on MyD88 $(P=0.025)$ and phosphorylated IKBa $(P=0.018)$

miRNAs, such as miR-155, miR-146, miR-21, miR-147, miR-9 have been identified to regulate the amplitude of the innate immune response by directly targeting the TLR pathway components or indirectly regulating other networks that cross-talk with TLRs [5, 24, 26, 27, 29]. We surmise that these miRNAs are also probably upregulated by maternal undernutrition and act to repress the TLRs signaling pathway proteins translation process. Furthermore, Ellis et al. [12], using microarray analysis, found that prenatal undernutrition and postnatal leptin treatment led to a limited liver programing, which was associated with increased inflammatory markers and downregulated antigen presentation genes that may lead to immunosuppression. Thus, unchanged hepatic toll-like receptor signaling pathway proteins expression may also be an appearance of immunosuppression. Certainly, more precise experiments are needed to further verify these processes.

\section{Conclusion}

There were three major findings from this study: 1) maternal feed intake restriction during the middle period of gestation led to an arrested development of the fetuses, especially of the heart; 2) maternal feed intake 
restriction affected the synthesis of acute phase proteins and alkaline phosphatase; and 3) maternal feed intake restriction mainly regulated the mRNA expression of genes involved in MyD88-dependent signaling pathways and of target cytokines. Further investigations should determine the processes of immune system responses to maternal malnutrition.

\section{Abbreviations}

ALB: Albumin; ALP: Alkaline phosphatase; BCAA: Branched-chain amino acid; IFN- $\beta$ : Interferon- $\beta$; IRAK1: Interleukin-1 receptor-associated kinase 1; IRF3: Interferon regulatory factor 3; IKBa: Inhibitor of nuclear factor kappa-B kinase; MyD88: Myeloid differentiation primary response 88; NFKB1: Nuclear factor kappa B subunit 1; NFKBIA: NFKB inhibitor alpha; PAMPs: Pathogenassociated molecular patterns; PON: Paraoxonase; SAA: Serum amyloid protein A; TGF- $\beta$ : Transforming growth factor- $\beta$; TLRs: Toll-like receptors; TRAF6: TNF receptor associated factor 6; TRIF: Toll like receptor adaptor molecule 1; UCB: Umbilical cord blood

\section{Acknowledgements}

The authors thank the National Natural Science Foundation of China for financial support.

\section{Funding}

This work was jointly supported by the National Natural Science Foundation of China (Grant No. 31760678, 31730092) and Youth Innovation Team Project of ISA, CAS (2017QNCXTD_ZCS).

\section{Availability of data and materials}

All data generated or analyzed during this study are available from the corresponding author upon reasonable request.

\section{Authors' contributions}

WXC and HY led performance of the experiments, the analysis of the data, and the writing of the paper. XLZ participated in the animal feeding trials. QXY participated in designing the experiments and editing the paper. All authors read and approved the final manuscript.

\section{Ethics approval}

All animal care and procedures were approved by the Animal Care and Use Committee of Institute of Subtropical Agriculture in compliance with the Regulations for the Administration of Affairs Concerning Experimental Animals (The State Science and Technology Commission of the People's Republic of China, 1988). The experiment was conducted at Institute of Subtropical Agriculture, The Chinese Academy of Sciences, Changsha, China.

\section{Consent for publication}

Not applicable.

\section{Competing interests}

The authors declare that they have no competing interests.

\section{Author details}

CAS Key Laboratory for Agro-Ecological Processes in Subtropical Region, National Engineering Laboratory for Pollution Control and Waste Utilization in Livestock and Poultry Production, Hunan Provincial Engineering Research Center for Healthy Livestock and Poultry Production, South-Central Experimental Station of Animal Nutrition and Feed Science in Ministry of Agriculture, Institute of Subtropical Agriculture, Chinese Academy of Sciences, Changsha, Hunan 410125, People's Republic of China. ${ }^{2}$ University of Chinese Academy of Sciences, Beijing 100049, People's Republic of China. ${ }^{3}$ College of Animal Science, Tarim University, Alaer 843300, People's Republic of China. ${ }^{4}$ Hunan Co-Innovation Center of Animal Production Safety, CICAPS, Changsha, Hunan 410128, People's Republic of China. ${ }^{5}$ Institute of Subtropical Agriculture, Chinese Academy of Sciences, Changsha, Hunan, People's Republic of China.
Received: 22 October 2018 Accepted: 17 February 2019

Published online: 16 April 2019

\section{References}

1. Alvesrosa F, Vulcano M, Beigierbompadre M, Fernández G, Palermo M Isturiz MA. Interleukin-1 beta induces in vivo tolerance to lipopolysaccharide in mice. Clin Exp Immunol. 2010;128:221-8.

2. Badr G, Sayed D, Alhazza IM, Elsayh Kl, Ahmed EA, Alwasel SH. T lymphocytes from malnourished infants are short-lived and dysfunctional cells. Immunobiology. 2011;216:309-15. https://doi.org/10.1016/j.imbio.2010.07.007.

3. Barker D, Osmond C. Infant mortality, childhood nutrition, and Ischaemic heart disease in England and Wales. Lancet. 1986;327:1077-81. https://doi. org/10.1016/S0140-6736(86)91340-1.

4. Barker DJP, Osmond C, Winter PD, Margetts B, Simmonds SJ. Weight inf infancy and death from ischaemic heart disease. Lancet. 1989:334:577-80. https://doi.org/10.1016/S0140-6736(89)90710-1.

5. Bin T, Bin X, Zhen L, Na L, En-Dong Z, Bo-Sheng L, Qing-Hua X, Yuan Z, Quan-Ming Z, Xu-Hu M. Identification of MyD88 as a novel target of miR155 , involved in negative regulation of helicobacter pylori-induced inflammation. FEBS Lett. 2010;584(8):1481-6.

6. Boylan JM, Sanders JA, Gruppuso PA. Regulation of fetal liver growth in a model of diet restriction in the pregnant rat. Am J Physiol Regul Integr Comp Physiol. 2016;311(3):R478-88

7. Calder PC, Yagoob P. The level of protein and type of fat in the diet of pregnant rats both affect lymphocyte function in the offspring. Nutr Res. 2000;20:995-1005.

8. Chandra RK. Nutrition and the immune system from birth to old age. Eur J Clin Nutr. 2002:56(Suppl 3):S73.

9. Chandra RK. Antibody formation in first and second generation offspring of nutritionally deprived rats. Science. 1975;190:289-90. https://doi.org/10.1126/ science.1179211.

10. Crispe IN. The liver as a lymphoid organ. Annu Rev Immunol. 2009;27:147-63.

11. D Prezotto L, E Camacho L, O Lemley C, E Keomanivong F, S Caton J, et al. Nutrient restriction and realimentation in beef cows during early and midgestation and maternal and fetal hepatic and small intestinal in vitro oxygen consumption. Animal. 2016;10(5):829-37.

12. Ellis PJ, Morris TJ, Skinner BM, Sargent CA, Vickers MH, et al. Thrifty metabolic programming in rats is induced by both maternal undernutrition and postnatal leptin treatment, but masked in the presence of both: implications for models of developmental programming. BMC Genomics. 2014;15(1):49.

13. Equils O, Singh S, Karaburun S, Lu D, Thamotharan M, Devaskar SU. Intrauterine growth restriction downregulates the hepatic toll like receptor-4 expression and function. Clin Dev Immunol. 2005;12:59-66. https://doi.org/ 10.1080/17402520400008905.

14. Fowden AL. Intrauterine programming of physiological systems: causes and consequences. Physiology. 2006;21:29. https://doi.org/10.1152/physiol.00050.2005.

15. Gao F, Liu Y, Li L, Li M, Zhang C, et al. Effects of maternal undernutrition during late pregnancy on the development and function of ovine fetal liver. Anim Reprod Sci. 2014;147(3-4):99-105.

16. Gluckman PD, Hanson MA, Bateson P, Beedle AS, Law CM, Bhutta ZA, et al. Towards a new developmental synthesis: adaptive developmental plasticity and human disease. Lancet. 2009:373:1654-7. https://doi.org/10.1016/S01406736(09)60234-8.

17. Gruys E, Toussaint MJM, Niewold TA, Koopmans SJ. Acute phase reaction and acute phase proteins. J Zhejiang Univ Sci B. 2005;6:1045-56. https://doi. org/10.1631/jzus.2005.B1045.

18. He Z, Sun Z, Liu S, Zhang Q, Tan Z. Effects of early malnutrition on mental system, metabolic syndrome, immunity and the gastrointestinal tract. J Vet Med Sci. 2009;71:1143-50. https://doi.org/10.1292/jvms.71.1143.

19. He ZX, Sun ZH, Yang WZ, Beauchemin KA, Tang SX, Zhou CS, et al. Effects of maternal protein or energy restriction during late gestation on immune status and responses to lipopolysaccharide challenge in postnatal young goats. J Anim Sci. 2014;92:4856-64. https://doi.org/10.2527/jas.2014-7904.

20. He ZX, Wu DQ, Sun ZH, Tan ZL, Qiao JY, Ran T, et al. Protein or energy restriction during late gestation alters fetal growth and visceral organ mass: an evidence of intrauterine programming in goats. Anim Reprod Sci. 2013; 137:177-82. https://doi.org/10.1016/j.anireprosci.2013.01.005.

21. Holt PG, Jones CA. The development of the immune system during pregnancy and early life. Allergy. 2000;55:688-97. https://doi.org/10.1034/j. 1398-9995.2000.00118.x. 
22. Jacometo CB, Osorio JS, Socha M, Corrêa MN, Piccioli-Cappelli F, Trevisi E, et al. Maternal consumption of organic trace minerals alters calf systemic and neutrophil mRNA and microRNA indicators of inflammation and oxidative stress. J Dairy Sci. 2015;98:7717-29. https://doi.org/10.3168//ds.2015-9359.

23. Kwon H, Ford SP, Bazer FW, Spencer TE, Nathanielsz PW, Nijland MJ, et al. Maternal nutrient restriction reduces concentrations of amino acids and polyamines in ovine maternal and fetal plasma and fetal fluids. Biol Reprod. 2004;71:901-8. https://doi.org/10.1095/biolreprod.104.029645.

24. Lai L, Azzam KM, Lin WC, Rai P, Lowe JM, et al. MicroRNA-33 regulates the innate immune response via ATP binding cassette transporter-mediated remodeling of membrane microdomains. J Biol Chem. 2016;291:19651.

25. Livak KJ, Schmittgen TD. Analysis of relative gene expression data using real-time quantitative PCR and the 2(-Delta Delta $C(T))$ method. Methods. 2001;25:402-8. https://doi.org/10.1006/meth.2001.1262.

26. O'Neill LA, Sheedy FJ, Mccoy CE. MicroRNAs: the fine-tuners of toll-like receptor signalling. Nat Rev Immunol. 2011;11:163-75.

27. Quinn SR, O'Neill LA. A trio of microRNAs that control toll-like receptor signalling. Int Immunol. 2011;23:421.

28. Racanelli V, Rehermann B. The liver as an immunological organ. Hepatology. 2006;43:S54-62. https://doi.org/10.1002/hep.21060.

29. Huang RS, Hu GQ, Lin B, ZY, Sun CC. MicroRNA-155 silencing enhances inflammatory response and lipid uptake in oxidized low-density lipoproteinstimulated human THP-1 macrophages. Journal of investigative medicine the official publication of the American federation for. Clin Res. 2010;58:961-7.

30. Takeuchi O, Akira S. Pattern recognition receptors and inflammation. Cell. 2010;140:805-20. https://doi.org/10.1016/j.cell.2010.01.022.

31. Tili E, Michaille JJ, Cimino A, Costinean S, Dumitru CD, Adair B, et al. Modulation of miR-155 and miR-125b levels following lipopolysaccharide/ TNF-a stimulation and their possible roles in regulating the response to endotoxin shock. J Immunol. 2007;179:5082-9.

32. Wu G, Pond WG, Ott T, Bazer FW. Maternal dietary protein deficiency decreases amino acid concentrations in fetal plasma and allantoic fluid of pigs. J Nutr. 1998;128:894-902.

33. Zhang HF. Nutrition parameters and feeding standard for animals. Beijing, CN: China agriculture press; 2010

Ready to submit your research? Choose BMC and benefit from:

- fast, convenient online submission

- thorough peer review by experienced researchers in your field

- rapid publication on acceptance

- support for research data, including large and complex data types

- gold Open Access which fosters wider collaboration and increased citations

- maximum visibility for your research: over $100 \mathrm{M}$ website views per year

At $\mathrm{BMC}$, research is always in progress.

Learn more biomedcentral.com/submissions 